Meta

Journal des traducteurs

Translators' Journal

\title{
Cross-Cultural Networking: Translators in the French-German Network of Petites Revues at the End of the Nineteenth Century
}

\section{Anthony Pym}

Volume 52, numéro 4, décembre 2007

La traduction et les études de réseaux

Translation and Network Studies

URI : https://id.erudit.org/iderudit/017695ar

DOI : https://doi.org/10.7202/017695ar

Aller au sommaire du numéro

Éditeur(s)

Les Presses de l'Université de Montréal

ISSN

0026-0452 (imprimé)

1492-1421 (numérique)

Découvrir la revue

Citer cet article

Pym, A. (2007). Cross-Cultural Networking: Translators in the French-German Network of Petites Revues at the End of the Nineteenth Century. Meta, 52(4), 744-762. https://doi.org/10.7202/017695ar

\section{Résumé de l'article}

Un réseau de petits périodiques littéraires a permis la dissémination des principes de l'Esthétisme de Paris dans tout le monde industrialisé vers la fin du XIX ${ }^{\mathrm{e}}$ siècle. Ces publications ont tissé des liens évidents au-delà des frontières nationales, et ces liens ont pris la forme de traductions qui ont contribué à la diffusion de connaissances et à l'établissement d'un certain sens d'appartenance artistique. Toutefois, les relations au sein même de ce réseau pouvaient s'avérer fortement négatives, diverses stratégies de réception usant de traductions et de commentaires pour défendre un esthétisme national plutôt qu'international. Lors de périodes de tensions politiques entre la France et l'Allemagne, ces relations furent compliquées davantage par l'utilisation d'un espace interculturel plus étendu. Dès 1871, les liens transculturels au sein du réseau ont fait graviter de plus en plus d'intermédiaires de Belgique, de Hollande, d'Alsace et de Suisse, espaces culturels situés entre les principaux centres du réseau France-Allemagne. Un désir d'espace interculturel plus centralisé s'est toutefois manifesté en 1895 lorsque le Mercure de France et le Neue deutsche Rundschau ont organisé conjointement des enquêtes sur les relations culturelles entre la France et l'Allemagne. L'utilisation stratégique de l'espace interculturel dans ces circonstances peut être montré en suivant les traductions en français de Wagner et Nietzche, qui auraient pu étendre le réseau et permettre une meilleure compréhension interculturelle. À la fin du siècle, toutefois, la plupart des relations potentiellement positives ont pris fin et les intermédiaires ont choisi leur camp. Les points de contact du réseau, y compris les traducteurs et les traductions, ont commencé à souligner les différences plutôt que les rapprochements, au moment où l'Europe basculait vers les guerres du $\mathrm{xx}^{\mathrm{e}}$ siècle.
Ce document est protégé par la loi sur le droit d'auteur. L’utilisation des services d’Érudit (y compris la reproduction) est assujettie à sa politique d'utilisation que vous pouvez consulter en ligne.

https://apropos.erudit.org/fr/usagers/politique-dutilisation/ 


\title{
Cross-Cultural Networking: Translators in the French-German Network of Petites Revues at the End of the Nineteenth Century
}

\author{
ANTHONY PYM \\ Universitat Rovira i Virgili, Tarragona, Spain* \\ anthony.pym@urv.net
}

\section{RÉSUMÉ}

Un réseau de petits périodiques littéraires a permis la dissémination des principes de l'Esthétisme de Paris dans tout le monde industrialisé vers la fin du xixe siècle. Ces publications ont tissé des liens évidents au-delà des frontières nationales, et ces liens ont pris la forme de traductions qui ont contribué à la diffusion de connaissances et à l'établissement d'un certain sens d'appartenance artistique. Toutefois, les relations au sein même de ce réseau pouvaient s'avérer fortement négatives, diverses stratégies de réception usant de traductions et de commentaires pour défendre un esthétisme national plutôt qu'international. Lors de périodes de tensions politiques entre la France et l'Allemagne, ces relations furent compliquées davantage par l'utilisation d'un espace interculturel plus étendu. Dès 1871 , les liens transculturels au sein du réseau ont fait graviter de plus en plus d'intermédiaires de Belgique, de Hollande, d'Alsace et de Suisse, espaces culturels situés entre les principaux centres du réseau France-Allemagne. Un désir d'espace interculturel plus centralisé s'est toutefois manifesté en 1895 lorsque le Mercure de France et le Neue deutsche Rundschau ont organisé conjointement des enquêtes sur les relations culturelles entre la France et l'Allemagne. L'utilisation stratégique de l'espace interculturel dans ces circonstances peut être montré en suivant les traductions en français de Wagner et Nietzche, qui auraient pu étendre le réseau et permettre une meilleure compréhension interculturelle. À la fin du siècle, toutefois, la plupart des relations potentiellement positives ont pris fin et les intermédiaires ont choisi leur camp. Les points de contact du réseau, y compris les traducteurs et les traductions, ont commencé à souligner les différences plutôt que les rapprochements, au moment où l'Europe basculait vers les guerres $\mathrm{du} x \mathrm{x}^{\mathrm{e}}$ siècle.

\footnotetext{
ABSTRACT

A network of small literary periodicals distributed the principles of Paris-based Aestheticism throughout the industrialized world at the end of the nineteenth century. These publications formed clear links across national borders, and those links were often manifested as translations that helped disseminate knowledge and form a sense of artistic belonging. However, the relations within the network could also be actively negative, as various receptive strategies used translations and commentaries to defend national rather than international aesthetics. In periods of political tension between France and Germany, such relations were further complicated by use of a wider intercultural space. From 1871, cross-cultural links in the network significantly drew on intermediaries from Belgium, Holland, Alsace and Switzerland, cultural spaces between the main centers of the French-German network. A more centralized desire for intercultural space was nevertheless manifested in 1895, when the Mercure de France and the Neue deutsche Rundschau jointly organized questionnaire surveys of the cultural relations between France and Germany. The strategic use of intercultural space in these circumstances can be shown by following the translations into French of Wagner and Nietzsche, which could have extended the network and increased cross-cultural understanding. By the end of
} 
the century, however, most of the potentially affirmative relations had unraveled and intermediaries began to take sides. The points of contact in the network, including the translators and translations, began to mark out differences rather than extensions, as Europe tilted toward the wars of the twentieth century.

\section{MOTS-CLÉS/KEYWORDS}

cross-cultural links, French-German network, nineteenth century, small literary periodicals

\section{A longish introduction on methodology}

Despite manifold sophistication, network analysis is about joining up the dots. The dots themselves can be anything: people, texts, or institutions, all of which might be termed "agents" (if and when we know something about their agency). More interesting perhaps are the lines that do the joining, which represent relations or exchanges of some kind. Those connections (conversation, agreement, influence, conflict, cooperation) are habitually more complex and unstable than are simple lines; they usually concern not just communication but also the potential to act through communication; and they concern not just agency but more especially co-agency, the capacity to act in relation. Those complex relations deserve something more than mere lines. One might associate networks with the exchange of goods and services, as has been done in now classical approaches that underscore the role of networks as social realities (cf. Boissevain 1974, Kapferer 1969). One might see networks as forming and reinforcing norms, and thus building institutions (Mitchell 1973). Or one might talk about negotiation as the relational counterpart of networks, where communication is presumed to be in search of mutual benefits (in terms of which, agreement and disagreement are understood as actions): "Messages which pass along network links can be seen as transactions, governed by the principle that the value gained by an individual is equal to, or greater than, the cost" (Milroy 1987: 47-48). That principle is called cooperation. It is worth retaining, with all its methodological consequences.

The search for cooperation is the line I took when seeking methodology in the pair réseau and régime (Pym 1988), dubbed network and negotiation in English so as to preserve the alliteration (Pym 1993, 1998a). The network is the material configuration of space and time; the regimes of communication organize potential cooperation across that space and time. On that view, there must be at least two levels of analysis, not one, since the simple lines are not eloquent enough. One must go beyond the diagrams that join up the dots. Older now, and perhaps wiser, I insist all the more that the relationships are much trickier than lines, and I freely concede that cooperation is an ideal undermined by numerous cultural strategies that give networks actively negative links (cf. the "manipulators" in Kapferer 1969 and Boissevain 1974), of which we shall soon see a few.

At the same time, the dots and lines are more than banal illustrations. The truly subversive interest of networks lies not particularly in the dots themselves, nor even in the relations represented by lines, but precisely in the distance that the lines purport to cross. That distance says that not all the dots occupy the same place. They must somehow be on the same communication level or set of levels (plexity will be one of our concerns here), but they are initially positioned apart. Network analysis says the communicators are different and in materially different positions. They are 
not all immediately dissipated into the same language, culture, class, or indeed any other quick category assumed to be a big dot. This is the point made by Milroy within sociolinguistics: "The basic postulate [of network analysis] is that people interact meaningfully as individuals, in addition to forming parts of structured, functional institutions such as classes, castes or occupational groups" (1987: 45-46). That is why network analysis has been part of sociolinguistics, ostensibly since Barnes' 1954 study of a Norwegian village. People cannot be reduced to sets of sociological categories; they cannot simply be slotted into languages or cultures; they create and act in their own space; they open and configure their own distances.

The particular interest of networks for Translation Studies thus ensues from what need not be assumed. Translators have always been difficult to place in abstract categories. Do they belong to the source culture or the target culture? Are they operating in the interests of one system or the other? There are usually so few individuals involved, and they are mostly of such varied disposition and provenance, that the homogeneous categories make little sense. Network analysis subordinates the categories to material distance. Rather than risk vast reductive assumptions about where translators are and what they do, networks invite us to grasp the ways in which they have configured their own spaces. They potentially allow us to see exactly when and how translators operate in history, in exchange with whom, and in what kind of space and time.

Our approach here is thus not immediately to be associated with the kind of mathematical social network analysis developed by Harvard sociologists in the 1960s (cf. Berkowitz 1982), precisely because the statistics tend to sublimate the materiality of time and space. Nor are we fully paid-up subscribers to the actor-network theory of Bruno Latour $(1987,1988)$. Latour's texts are fashionably French and sufficiently abrasive to find adepts in disparate places. Of course, we are in agreement with many of the positions he holds, especially with respect to the way the fibrous maps of networks undermine and undo facile social categories. As we shall see, network analysis shows that the relations between French and German cultures were anything but a simple line of division, a border, with people working one side or the other. We baulk, however, at precisely the level at which Latour invests most of his intellectual efforts. We cannot accept, first, that there is nothing but network, that there is a single-level ontology to social life. This does not mean we seek any permanent separation of social organization from behavior, position from action, base from superstructure. But it does mean that we want to allow methodologically for marked contradictions to appear between the material distribution of networks (what people do and where they do it) and the ideological configurations of belonging (what they say and think they do, and where they say and think they are). The deceptively homogeneous social categories ("French culture" vs. "German culture" in our case study) do intervene; people do have a fabricated sense of being positioned one side or the other, even when their material positions say otherwise; their "illusions are not illusory" (Bourdieu 1980: 32). Indeed, this non-networking illusion of "one side or the other" is one of the powerful logics that translations produce. That is basically why we require at least two levels of analysis, not one.

Second, we find it unnecessary to suppose that physical distance is somehow devoid of a type of agency in the construction of networks, as if postmodern technology really had configured the globe into a mode of immediate presence ("meaning 
productions" for Latour). Not enough is said about material distance, the one across which subjects become communication partners. Part of that distance concerns the physical realities of time and space, the material resistance to messages in movement. Another part comprises the many historical technologies that counter that resistance. The oral proximity of voices in a village bar in Norway is a deceptively immediate presence. The technologies of inscription carry messages across far greater distances, in many varied forms, starting from the gramme that Derrida (1967) placed anterior to the letter and which gives the fundamental displacements of language. Texts move from situation to situation, generation to generation, culture to culture, through the historical drama of technologies encountering the resistance of time and space. Networks are the stuff of the century-leaping genealogies by which manuscript traditions are formed (medievalists have been sketching those kinds of networks for a century). They fill out the distribution areas allowed by print, in the time frames facilitated by horse, shipping, the railway, electronic communication. More important, in the drama of technology against distance, the discontinuous categories of relative proximity play a powerful iconic role in the construction of belonging. To talk in terms of our case study, it does matter whether a communication partner is physically in Germany or France. It does matter that Belgium, Alsace or Switzerland had geopolitical densities that resisted straight cultural flows between France and Germany. And it does matter whether intermediaries came from those middle cultural spaces, or indeed whether their families were from there (to map the discontinuities over time). At the same time (and here we rejoin Latour), it also matters that the canals and roads of the north-east of France were particularly well developed at the end of the nineteenth century, forming a specific European awareness. Communications circulated faster in that part of the country; there was a special consciousness of development alongside Germany, in proximity, rivalry and similitude with the traditional enemy.

Our task here is to follow the cultural networks that crossed the national border, without annulling the power of that border.

\section{Network zones}

With those excuses, we work from the fairly pragmatic kind of network analysis found in English-language sociolinguistics. How can we conceptualize a network crossing a border that is not properly part of the network? A simple model comes from Milroy's work on the sociolinguistics of Belfast, where we find the following diagram of two related "network zones" (Figure 1): 
FIGURE 1

Network zones, from Milroy 1987: 48 ("second order" is defined from the perspective of the anchor point $\mathrm{X}$ )

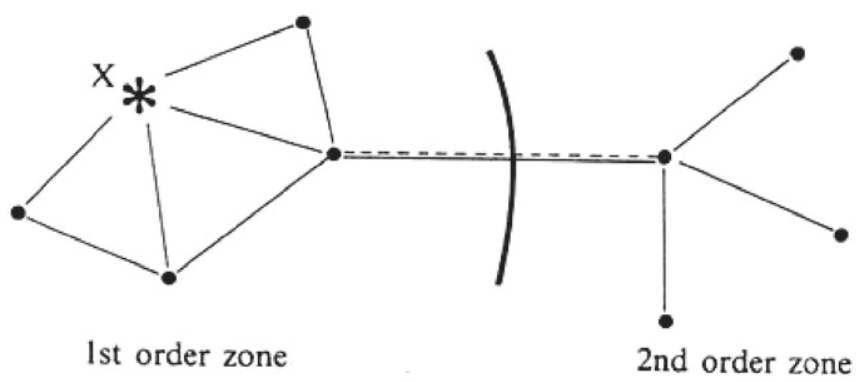

That looks easy enough. In the Belfast research, this model served to explain how the sociolinguist entered the network as a "friend of a friend," passing from the secondorder zone to make contact with the intimacy of community life in the first-order zone. The model also implicitly explains how language change was occurring in Belfast, as women from the poorer areas went to work as cleaners and the like in the richer areas, thus moving between first and second orders of a kind. The border or barrier might thus be between the object of study and the researcher (yes, our own activity is in the network), but also, on another level, between one geographical place and another. The important point is that lines can cross the boundary. That much, at least, is necessary for translation.

Let us now try to apply the zone model to relations between France and Germany. The basic map could work, with the national cultures thus becoming zones of a much more complicated kind, although the principle of entry by a "friend of a friend" is perhaps less evident. A writer, or a text, could gain entry from one side to the other through the mediation of a critic or translator, who would thus become the friends who introduce their friends. But the analogy is not to be forced. The important point is that the simple network model enables us to accept communication between zones. If the national cultures are so complex as to be systems, then in this model they are not the kind of "pure communication" systems assumed by Luhmann (e.g. 1995), since here there is communication between the two sides (Luhmann only allows for "irritation" between systems in contact). Nor can translation immediately be reduced to a "boundary maintenance" mechanism (cf. Parsons 1951), operating to define and protect the limits of a system (or indeed of both systems). Boundary maintenance is certainly something that translations do. The zone model, however, is inviting us to map communication in more fully transactional terms.

If we attempt to map the "network zones" in the relations between literary periodicals in France and Germany in the later part of the nineteenth century, some problems are immediately obvious. First, we have to map both space and time, since one particular kind of periodical, the petite revue form, starts in France then spills over into Germany, and only a time axis can show this. Second, we have to allow for an intermediary space for a few bilingual periodicals, perhaps to be seen as places 
where "friend-bearing friends" might congregate. And third, the relations between the two sides inevitably bring in further intermediary spaces, in this case journals in Belgium. We thus get something like Figure 2.

\section{FIGURE 2}

Temporary scaffolding for a network of petites revues operating on French-German relations

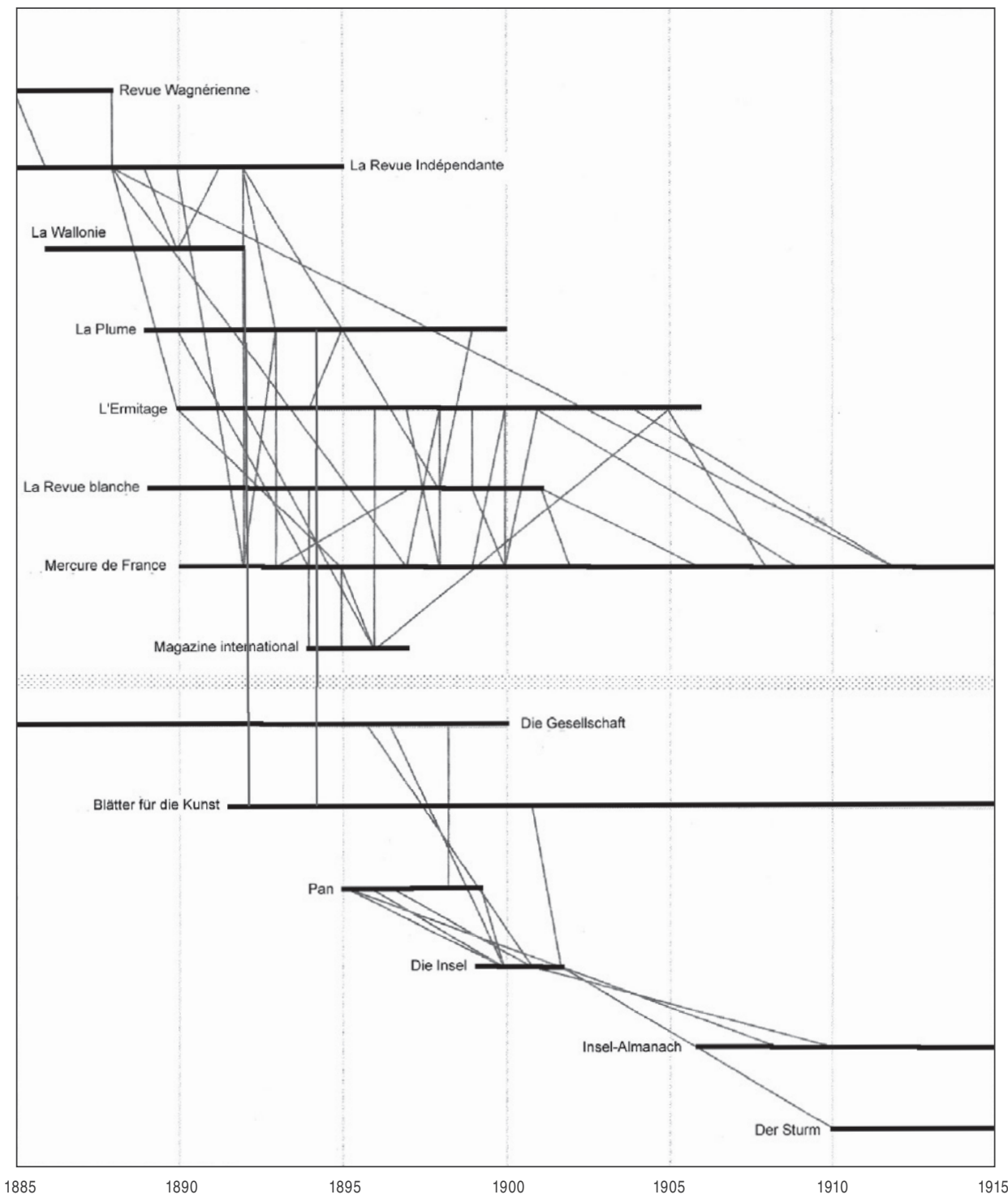

Of course, the form of Figure 2 cannot be considered at all complete. It is no more than one stage in an incremental approach that can be developed in many further directions. What we have presented might best be described as the basic scaffolding 
for research on the network that concerns us. The connecting lines are fairly easily accompanied by a tracking of the translations appearing in most of these periodicals, the data on which appear in Table 1 (where we have simply counted the pages that carry translations, no matter what the genre or source language involved). We thus have a first image of the historical space occupied by the network, and an equally rough picture of how many translations were traveling through that network.

TABLE 1

Pages with translations, French and German literary periodicals, 1885-1904

\begin{tabular}{|l|c|c|c|c|c|c|c|c|c|c|c|c|c|c|c|c|c|c|c|c|}
\hline & 85 & 86 & 87 & 88 & 89 & 90 & 91 & 92 & 93 & 94 & 95 & 96 & 97 & 98 & 99 & 00 & 01 & 02 & 03 & 04 \\
\hline Wagnérienne & 8 & 2 & & & & & & & & & & & & & & & & & & \\
\hline Indépendante & & 2 & 2 & 8 & 4 & 1 & 2 & 6 & & & & & & & & & & & & \\
\hline La Wallonie & & 0 & 0 & 0 & 0 & 3 & 0 & 0 & & & & & & & & & & & & \\
\hline La Pluma & & & & & & 4 & 1 & 1 & 5 & 4 & 4 & 0 & 1 & 0 & 1 & & & & & \\
\hline L'Ermitage & & & & & & 1 & 1 & 5 & 2 & 3 & 1 & 6 & 1 & 2 & 5 & 8 & 6 & 8 & 5 & $\mathbf{3}$ \\
\hline Blanche & & & & & & & & 5 & 2 & 0 & 5 & 6 & 8 & 6 & 6 & 12 & 12 & & & \\
\hline Mercure & & & & & & & 4 & 16 & 11 & 10 & 11 & 4 & 5 & 9 & 10 & 9 & 4 & 5 & 3 & $\mathbf{1}$ \\
\hline Magazine & & & & & & & & & & 15 & 16 & 53 & & & & & & & & \\
\hline Total French & $\mathbf{8}$ & $\mathbf{4}$ & $\mathbf{2}$ & $\mathbf{8}$ & $\mathbf{4}$ & $\mathbf{9}$ & $\mathbf{8}$ & $\mathbf{3 3}$ & $\mathbf{2 0}$ & $\mathbf{3 2}$ & $\mathbf{3 7}$ & $\mathbf{6 9}$ & $\mathbf{1 5}$ & $\mathbf{1 7}$ & $\mathbf{2 2}$ & $\mathbf{2 9}$ & $\mathbf{2 2}$ & $\mathbf{1 3}$ & $\mathbf{8}$ & $\mathbf{4}$ \\
\hline Gesellschaft & 3 & 1 & 0 & $\mathbf{5}$ & 1 & 3 & 0 & 3 & 1 & 3 & 1 & 4 & 0 & 42 & 18 & 17 & & & & \\
\hline Blätter & & & & & & & & 4 & 6 & 5 & 1 & 5 & 0 & 0 & 4 & 3 & 1 & 2 & 0 & $\mathbf{1}$ \\
\hline Pan & & & & & & & & & & & 11 & 5 & 2 & 1 & 4 & & & & & \\
\hline INSEM & & & & & & & & & & & & & & & 1 & 11 & 11 & 23 & 25 & \\
\hline Total German & $\mathbf{3}$ & $\mathbf{1}$ & $\mathbf{0}$ & $\mathbf{5}$ & $\mathbf{1}$ & $\mathbf{3}$ & $\mathbf{0}$ & $\mathbf{7}$ & $\mathbf{7}$ & $\mathbf{8}$ & $\mathbf{1 3}$ & $\mathbf{1 4}$ & $\mathbf{2}$ & $\mathbf{4 3}$ & $\mathbf{9}$ & $\mathbf{1 4}$ & $\mathbf{1 2}$ & $\mathbf{2 5}$ & $\mathbf{2 5}$ & $\mathbf{1}$ \\
\hline TOTAL & $\mathbf{1 1}$ & $\mathbf{5}$ & $\mathbf{2}$ & $\mathbf{1 3}$ & $\mathbf{5}$ & $\mathbf{1 2}$ & $\mathbf{8}$ & $\mathbf{4 0}$ & $\mathbf{2 7}$ & $\mathbf{4 0}$ & $\mathbf{5 0}$ & $\mathbf{8 3}$ & $\mathbf{1 7}$ & $\mathbf{6 0}$ & $\mathbf{4 6}$ & $\mathbf{6 0}$ & $\mathbf{3 4}$ & $\mathbf{3 8}$ & $\mathbf{3 3}$ & $\mathbf{5}$ \\
\hline
\end{tabular}

That empirical basis can grow or retract as required. In itself, it does not offer any kind of understanding of what was happening. The numbers of translations clearly rise in both French and German as the 1890s progress; they taper off with the new century. Does this mean there was a period of greater international exchange and awareness? Or are these mere accidents? In our data, the Belgian journal La Wallonie hardly translates at all (just a few pages of Swinburne), so should we conclude that the Belgian intermediaries were of no importance? On the other hand, there are numerous translations in the ephemeral Magazine International, but what impact did they actually have on the rest of the network? The radical change of translation policy at Die Gesellschaft in its death throes from 1898 was probably no more than that. Then again, the presence of translations in the Mercure de France appears constant and patterned, and demands further investigation. Further, there are international periodicals such as Cosmopolis (1896) or the Revue franco-allemandel Deutsch-französische Rundschau (1899-1901) that did not translate at all, since they presented all texts in the original languages. So are we to exclude them from the realm of active intercultural mediation? The quantitative data alone are clearly insufficient. As we follow up the leads (the cases of Wagner and Nietzsche will be discussed below, the latter being of direct importance for the Mercure), the lines will multiply, the numbers will become acts of communication, the networked space and time will come into finer view, and some kind of causation might then be guessed at.

So much for the dots and the lines. 


\section{Constructing networks of journals}

We first turned to literary periodicals when we were having trouble ascertaining the social context of translators and other intermediaries. This was in the course of a research project on the cultural relations between France and Germany at the end of the nineteenth century, with specific attention to the way translations were related to the shadows of war. The literary periodicals turned out to be particularly useful on several counts. First, when approached as institutions, they gave a fairly precise ideological and sociological location for numerous ephemeral writers, critics and translators, in some cases enabling us to trace the movements of those people from one milieu to another. Second, the periodicals place translated and non-translated texts side by side, ostensibly for the same readership and often by the same author or translator, such that differences between the texts could be attributed to translational status and not to other causes. Third, the periodicals often contain traces of theorization processes, either as critical commentaries or as solutions to certain editorial problems about how translations and translators should be presented. Those are all quite practical reasons for using the periodicals as a major dimension of spatial analysis. They can become the material framework for a finer tracing of movements across the border.

In this particular frame, however, the petites revues become a genre of particular importance. This was a time when artists affirmed themselves as specific social groups, increasingly without reference to a wider public, ever more within an ideology of the avant-garde. When they came to write the history of this affirmation (mostly presented as the history of Symbolisme, but more exactly of Aestheticism), their spontaneous references were not to any strict schools or chefs-d'oeuvre but to periodicals and to manifestos published in periodicals.

If we are to set about drawing networks of these petites revues, where do we begin? One approach would be to compile a corpus of publications, then plot the links. Unfortunately there were far too many periodicals for that procedure to be efficient. According to the sociologist Alphonse Boubert (who was there at the time), 1,748 periodicals were being published in Paris in 1889, of which 56 specialized in literature (cited in La Plume 1.1, 15 avril 1889). In Germany, the lack of a central capital of culture makes publications rather more difficult to count. However, there seems to have been nothing like the same number of German periodicals focusing on literature and only literature. Schlösser states that in the years following 1900 there were some 25 newspapers and periodicals printing regular reviews of English literature (1937: 2). Although he finds this figure prohibitively high for a systematic analysis of the publications involved (he believes reception can be quantified directly from catalogues of printed books), the figure he gives is still much more inviting than the total for Paris. The field must somehow be reduced. This can partly be done by exploiting the divisions presented by the periodicals themselves.

Many of the publications that the sociologist Boubert classified as "literary" were servicing a very wide market. They should be understood as part of the mass-culture system of newspapers and series like the Bibliothèque bleue, which had been taking over from colportage distribution ever since the 1850s (Lyons 1987). Rail contacts greatly increased the speed of distribution, developing new relations between text and reader. Centralized and monopolized printing was in far more immediate contact 
with a regional or national public, driving out the remnants of popular or folk culture. Within the receding limits of literacy, mass-circulation publications were achieving a rapid extension of literary readerships. Newspapers and the lending libraries were also segmenting readerships, transforming the place of literariness within periodical publications.

The nineteenth century had developed two basic kinds of periodical publication in which literary texts could be published. The first might be called the "magazine," which included texts on numerous subjects and performed invaluable tasks of scientific divulgation, public debate and interdisciplinary exchange. The life of a successful magazine was typically long. However, the form would eventually succumb to the rise of newspapers as the century progressed, especially with respect to the publication in newspapers of novels by installments. The second kind of publication was the specialist literary "review," of which the most influential model was probably the Parnasse contemporain series. Responding to declining sales for published poetry, the task of the specialized review periodical was initially like that of a sales catalogue, giving samples of books that could be bought. The form also allowed for several further marketing strategies that were to guarantee its popularity. Its relatively quick publication rhythm and often consciously ephemeral status encouraged experimentation. Such was the commercial logic of the petite revue. These periodicals became places for discovering and developing whatever was new. They were where literature could be seen to happen. They thus brought writers together as short-term groups linked not by allegiance to any past master but by shared search for progress in a restricted field (for detailed accounts of the many small groupings, see Décaudin 1960). A magazine might develop a school of thought, as in the Romantic age; a petite revue could express a movement (or the shared desire for one), as in the Modernist avant-gardes.

These two models were available prior to the period that interests us. They did not stay the same, nor did not remain separate. When the rise of the newspaper killed off many of the general magazines, Naturalist aesthetics nevertheless stimulated continuation of the generalist approach. Through to the 1900s we thus find periodicals that bring together literary texts, sociology and popular science, in keeping with the Naturalist belief that progress applied indifferently to both art and society. On the other side of the coin, the (often but not always Aestheticist) petite revue presents a plethora of ephemeral publications that were fundamentally unable to establish any financial basis. Some enjoyed a short life because they were essentially extended concert programs, sold at musical concerts and through limited subscription lists (the Revue Wagnérienne, finding some inspiration in the Bayreuther Blätter). A few survived by becoming not just sample catalogues but full-blown publishing companies (Die Insel, Mercure de France). Others (notably La Plume) promoted social activities like poetry competitions, questionnaires, fund-raising to build statues (to Baudelaire), more fund-raising to care for sick poets (Verlaine), literary banquets, and poetry-reading soirées. Others went into ventures like a rare-book exchange (Mercure de France), sales of etchings and lithographs (particularly Der Sturm) or even the organization of painting classes (once again Der Sturm). The periodical could thus become something like a social club. Yet most Aestheticist periodicals remained temporary statements. The form developed its ephemeral status as the strength rather than weakness of its particular form of collective statement. 
Beyond France, Naturalism and Aestheticism tended to arrive together as the twin faces of Modernism, and the forms of many periodicals were correspondingly less defined. German literary periodicals nevertheless provide clear examples of both tendencies. Die Gesellschaft was a generalist magazine with marked political interests, little verse and some doubts as to where its literary criticism should be placed. The Blätter für die Kunst, on the other hand, was self-consciously a petite revue from the outset, with a minimum of prose and a tendency towards the purest of group poetic statements. Die Insel's relatively high proportion of prose should place it somewhere between the two models, although its increasing function as a publisher's catalogue pushed its later issues more firmly to the petite revue side of business.

As the turn of the century approached, decorist aesthetics overtook the Aestheticist/ Naturalist divide, moving literary discourses decidedly closer to the visual arts than to the musical inspiration of the 1880s. Periodicals thus increasingly combined literary texts with graphic art. The most extreme case was the luxurious Berlin periodical Pan, which was deservedly marketed more as a work of art in itself than as a periodical in any traditional sense. It is nevertheless of interest here, since it started with an Aestheticist-internationalist outlook and was then taken over by Naturalistnationalists, significantly changing its translation policy. The fact that the two ideologies could compete for the same periodical form indicates the extent to which they had come together by the end of the nineteenth century.

This kind of genre analysis allows us to focus on one particular kind of periodical in the Paris of the 1890s, at the center of the international network, but with less certitude of identifying the form as we move out to the periphery or forward in history. Could a genre-based corpus survive in a situation where the very features of the genre (the features by which we could select or exclude periodicals for analysis) are also moving and permuting through the network?

At this point we turn to an alternative approach. As in Latour's actor-network theory, we assume that the network defines itself from within. All we have to do is pick up the strands and follow them, including the strands that define our own relation to the network. In Method in Translation History (Pym 1998a), that method is described as "incremental," and the example given is roughly as follows.

\section{Tracing the network from within}

One Carl August noted in a letter to the Parisian periodical La Plume (15 mai 1893) that Germany, like Britain, had no real equivalent to the French petite revue. More precisely, there were no periodicals specializing in art and literature without more general political ties. August then lists the main German periodicals of the day: Kunst für Alle (Munich) dealt exclusively with painting, Moderne Kunst (Berlin) had only a small place for literature, Westermanns Monatshefte, presented as an equivalent of the prestigious Revue des Deux-Mondes, was for university professors and writers aged over forty (heaven forbid!). The new smaller periodicals like Magazin and Freihe Bühne were associated with Naturalism, filling their pages with news events and social questions about workers and women. Die Gesellschaft (Munich) also had its Naturalist agenda. And so, by convenient elimination, one arrives at the Blätter für die Kunst, apparently the only periodical truly corresponding to the French model. It was also the periodical that Carl August, under his full name of Carl August Klein, 
just happened to have been publishing since 1892. His letter nevertheless indicates the extent to which this particular German periodical was based on a particular French model. And French publication of the letter indicates a certain French desire to reflect the reflection.

Through this exchange, the two periodicals select each other. They form a link. A series of such links can constitute a self-selecting network, traced without great need for any excessive a priori criteria. Other contacts are in evidence. For example, the Belgian periodical $\mathrm{La}$ Wallonie, when reaching its final issue in 1892, warmly recommends the Blätter für die Kunst. Not surprisingly, La Wallonie is itself frequently mentioned in the columns of La Plume, as indeed are several other Frenchlanguage publications rallying to the Aestheticist cause. The Belgian connection could not be eliminated from the network. But there were many other kinds of contact going on, some of them concerning translations. Slightly previously (late 1891 and early 1892), the Parisian periodical L'Ermitage had published verse by Stefan George (the table of contents says "Stephane Georges") in German, with French translations by Albert Saint-Paul en regard. The translator notes that the German poet “inaugure en Allemagne, contre l'envahissement du naturalisme, le même mouvement de reaction que les Symbolistes français" (3/10, 585). George was of course the founder and main figure of the Blätter für die Kunst, published by the same Carl August (Klein) we met above. He would in turn translate verse by his translator Albert Saint-Paul in the May 1893 issue of the German periodical. There was thus a clear relation of exchange between the two poets, made quite understandable by George's residence in Paris at the beginning of the 1890s. Yet the relation also existed between the periodicals, as confirmed by publication in L'Ermitage of 1892 of an article by "Karl August" (the same publisher of the German periodical), this time arguing directly against the Naturalist periodical Die Gesellschaft. And so our image of the network grows.

This brief illustration has found links between four periodicals, two of them Parisian (La Plume and L'Ermitage), one francophone Belgian (La Wallonie) and one German (Blätter für die Kunst), with the latter opposed to Die Gesellschaft. This could be described as part of an Aesetheticist network, constructed and maintained in opposition to Naturalist publications. Further application of the method is what gave us Figure 2, a small international network of periodicals, the spaces of which can be filled out as research requires. Thanks to this network, periodicals could find support and enter into relations of exchange (or opposition) across national and linguistic borders.

However, as we anticipated, the relations are not quite that simple. Attention must be paid to the variety and quality of the links forming a network, and indeed to the kind of space occupied by this network as opposed to others.

\section{Relations within the network}

Rather than impose an abstract typology of relations (positive, negative, translational, non-translational, etc.), we can better serve incremental analysis by describing the main configurations as they emerge. In this case, the following types of relations quickly appear: 
1. The network is clearly centered on Paris. This is not only evident in the movement of the petite revue form and the pronounced directionality of the commentaries and translations, but also in several internal inconsistencies or contradictions. For a great many of the intermediaries, Paris is the first order zone, no matter where those intermediaries are from or the languages they are working into. Even when writing in German, figures like George and Nordau (along with many lesser lights) were living in Paris or passing through there. Linguistic space and geopolitical divisions are this out of kilter.

2. For most of the petites revues outside of Paris, relations with similar periodicals abroad are clearly more pronounced than are relations with any close or local entities. That is, strong links over distance correlate with weak links at home. This is a direct sociological consequence of the petite revue form itself. The more traditional periodicals still carried articles on politics, economics, fashion, publicity, and so on, and were thus necessarily linked with other local institutions. Aestheticism, however, required a focus on art alone, and the most prestigious external relations were with the avant-garde publications that provided the model of the genre. This was a powerful motivation for translations.

3. For the periodicals within Paris, there is a recognized hierarchy of prestige, usually expressed in terms of "old" symbolic value against the new. For instance, when Théodore de Wyzewa entered into a debate about translation in 1901, he did so as critic for the long-standing and prestigious Revue des Deux-Mondes. When he wrote letters to La Plume, it was thus with marked condescension. Such hierarchical relationships do much to maintain a culture in place. However, it is difficult to find quite the same relationships across national boundaries. German periodicals may project a hierarchical relationship with respect to other German periodicals, but not with specific reference to any periodical in Paris.

4. Some links are marked by an active negativity, usually within the same national space. As we have seen, within the space of German, the Aestheticist Blätter opposed the Naturalist Gesellschaft, thus developing the identity of both. However, all along the line, Naturalism constantly produced and distributed information on international Aestheticism, assisting and participating in the network it ostensibly opposed. In this, there was no clear division between the national and the international. Indeed, Naturalism helped distribute the figures of Aestheticism significantly beyond the periodical form, notably through Huysmans' ironic portrayal of the Aesthete in A rebours (1884), or Nordau's book-length denouncement of all aspects of Aestheticism in Entartung (1892-3) (translated into French as Dégénérescence in 1894), fragments of which were picked up in gossip columns across the globe. The 64 interviews included in Jules Huret's extensive Enquête (1891) were indeed within the periodical form (they originally appeared in L'Echo de Paris), providing much of the information on Aestheticism that was used not only in Nordau's denouncement but also in numerous Aestheticism petites revues. Much of the prose translated out of French thus came from such crossings of the Naturalist/Aestheticist divide.

5. Even though the thematic scope of the petite revue was ideally restricted to art and news about art, the internal social and commercial relations of the main periodicals 
could operate on many different levels. As we have noted above, there were fundraisers, painting exhibitions, banquets, a hundred pieces of informal sociology, and the epoch of absinthe, after all. The aesthetic ideology could thus be monoplex (only one level: art alone was what counted) while the social network was multiplex (many levels at the same time). The interest of this apparent paradox is that the Aestheticist translations going out of French tended not to reflect this multiplexity, which was only reported, if at all, in the Naturalist texts, usually in the form of scandal.

6. Translations in the network show a clear directionality outward from the center in Paris. This applies to both Aestheticism and Naturalism, to both poetic language and prose. There was nevertheless a significant number of translations published in the center, in the Parisian periodicals (see Table 1). Few of those translations could be said to bring anything radically new to the center in the way of content (Whitman being a possible exception). Their function was instead to reflect Parisian Aestheticism, providing internationalist feedback that could only strengthen the resolve of writers who had turned their back on mass culture. Some of the translators were young bilinguals seeking to use translation as a way of entering literary circles. The interesting point is that Paris was insecure enough to seek and use such support.

7. Among the German periodicals there was an ideological and aesthetic distinction between "internationalists" and "nationalists," particularly with respect to the reception of French literature. This was to be expected. What is surprising, however, is the extent to which the nationalists (mostly literary Naturalists of one shade or another) did in fact translate. The translations circulating through the network managed to serve both camps. In fact, the real split is only manifested when foreign texts were printed without translation, as happened in the case of Pan in 1895, before it was taken over by nationalists.

8. Most obviously, the relations between the periodicals were not determined by the periodicals alone. All forms of communication impinge on the networks, such that determining factors may come from book publication, public events, politics, economics, or indeed war. The very nature of periodical publication is to be open to the moment. A history focused on the petite revue alone would consequently give a very limited account of causation.

\section{Networks and intercultural space}

Our basic mapping of the periodical network, accompanied by data on the translations, may be used to test and develop any number of hypotheses. In the case of our own research, the principle hypothesis has been that the literary relations between France and Germany operated through intercultural space. In terms of this paper, we might say that the communication was carried out through a specific sub-network based on the overlap of the two cultures, operated by professionals whose task was to define the relations between the two major cultures. More bluntly, we posit that the cross-border communications were organized by an interculture.

Considerable evidence can be found in support of this hypothesis by focusing on the cultural positions of Belgium, Holland, Alsace and Switzerland, particularly with regard to critics and translators from these regions. In the years of tension fol- 
lowing the defeat of France by Prussia in 1870-1871, translators from these "buffer" zones were virtually the only French-speakers prepared to render German texts. This has been observed by Duméril in his study of the German Lied in France (1934: 253 255), where Swiss translators were the only ones prepared to bring Heine into French in the 1870s, followed by the French-speaking Dutch translator Beltjens. Even into the 1880s, the role of the Revue Wagnérienne and La Wallonie is strongly marked by this specific kind of interculturality (see our discussion of Wagner below), at the same time as the main German-speakers rendering French texts had traveled through Paris or had taken up residence there, posting their contributions to periodicals in Germany. In this kind of situation, one cannot say that the translation flows were determined by one culture or the other. They necessarily depend on the sub-networks specific to a nascent interculture.

That view works, more or less, for the period following 1871. Into the 1890s, however, the beauty of the interculturality hypothesis becomes rather harder to defend. We tell the story by briefly tracing the fortunes of two strands of translations: Wagner and Nietzsche, both into French.

\section{Wagner, from interculture to Paris}

After 1871, Wagner's operatic poems were translated into French by a good number of intercultural figures. An anonymous Walkyrie was published in Brussels in 1878; the Fleming Victor (van) Wilder signed a contract with Wagner's publisher Schott in 1885 and proceeded to render the operatic poems into French rhyming verse; another Belgian, Henri La Fontaine, produced a prose Walkyrie in Brussels in 1886; the Belgian Maurice Kufferath translated Wagner in Brussels from 1890. There were certainly other translators in the mix, but the Belgian connection was strong and not at all accidental. In the post-1871 context, particularly in view of Wagner's celebration of the French defeat in his farce Une capitulation, national pride virtually prohibited the French from touching Wagner. Belgians thus took up the role of intermediaries.

As this was happening to the north, Paris founded a petite revue dedicated precisely to Wagner: the Revue Wagnérienne of 1885-88. The Parisian periodical consistently criticized all the Belgian translators either for promoting populist understandings of Wagner or, often in the same breath, for not being able to write good French. Wilder and La Fontaine, for example, were belittled as "vulgarizing translators" (Dujardin 1886: 142). A kindred spirit at L'Ermitage, the Parisian critic Willy, ridiculed Kufferath's French as "the language of ragamuffins who spend their time picking up bullets from the battlefield of Beverloo" (1895: 42-43). Although Belgian interculturality was necessarily operative at this particular stage, it was quickly excluded in the name of a somehow truer, more centralized reception of Wagner. In this case, the role of the Parisian publication was to distance and repress the manifestly intercultural parts of the network.

The Parisian reception was not, however, as nationally centralized as it might appear. The Revue Wagnérienne, which placed Wagner on the French cultural map in ideologically difficult times, had among its main figures the Polish-born Théodore de Wyzewa and the Anglo-Swiss fascist Houston Stewart Chamberlain, both translators and faithful Wagnerians to the end. The periodical was formed when Wyzewa and Chamberlain met with Dujardin, not in Paris but in Bayreuth. These were 
people who moved backwards and forwards across intercultural space, presuming knowledge of both source and target cultures at a level somehow superior to that of mere intermediaries from Belgium. As such, they could all be painted with the same negative brush by the German Naturalist pseudo-sociologist Max Nordau (himself living in Paris): "The Bayreuth concert hall, the Bayreuther Blätter and the Parisian Revue Wagnérienne are all lasting monuments in which the future will be able to gauge the entire breadth and depth of our age's decadence and hysteria" (1892-3, 1, 332, our translation).

Dujardin and Chamberlain not only criticized the popularizing translators but also produced their own highly literalist versions, designed for an elite, the true Wagnerians, implicitly those of Paris. Interestingly enough, Dujardin declared that Wagner required two translations, one to introduce the uninitiated to the work, and the other, literalist, so that just a few people ("quelques uns") might appreciate the German text without having to learn German. This double-translation solution was actually a commercial strategy at the time. The publisher Hachette was publishing a pedagogical series called "Les auteurs allemands expliqués d'après une méthode nouvelle: par deux traductions françaises, l'une littérale et juxtalinéaire, l'autre correcte et précédée du texte allemand" ("German authors explained according to a new method: by two translations into French, one literal and interlinear, the other correct and preceded by the German text"). Translations could be either literal or correct. But we stray.

The peculiar thing about the Wagner reception is that this distinction was mapped onto the difference between the Parisian and Belgian parts of the network. Although one might suppose that people in intercultural space would exhibit greater linguistic contamination and thus greater literalism as translators, in this case the literalism was called for in Paris, precisely to oppose the domestication that came from the Belgians. In this way, initial intercultural mediation allowed Parisian reception to claim substantiality for its cultural centralism. The result of the international network was not at all internationalist.

Or was it? Successful literalism of the kind sought by Dujardin was eventually brought to the Parisian opera by Alfred Ernst from 1894, whose work aroused criticism from one Henry Baüer (sic) of the Echo de Paris for breaking French syntactic norms. According to Baüer, "Ernst's translation follows the movement of the musical period at the expense of the French phrase, to the detriment of the rules and even the genius of the French language" (cited Willy 1894: 382). Several paid-up Wagnerians then rose to the defense of Ernst's literalism. For Willy, the same Willy who ridiculed the Belgian translator Kufferath, "It is really Wagner that one hears or reads in Ernst" (1894: 382), none the least because archaisms and inversions were to be found in Wagner himself. The arguments used against the popularist Kufferath were not used against the elitist Ernst.

Yet intercultural space returns. Who was Alfred Ernst? His father was an Austrian violinist; his mother was a Jewish actress from Alsace who, in the 1870s, wrote best-selling patriotic verse under the title Rimes françaises d'une Alsacienne. The hero of elitist Parisian Wagnerians was also from passably intercultural space, indeed from the one physical space that could not be forgotten, Alsace. 


\section{Nietzsche français}

The French Nietzsche followed hot on the heels of Wagner, arriving by remarkably similar routes, none the least because Nietzsche was initially read as a critic of Wagner. The first translation into French was carried out by Marie Baumgartner (née Koechlin), an Alsatian whose translation Richard Wagner à Bayreuth was published in Basle in 1877. Other Alsatians involved in the reception of Nietzsche in the years through to 1910 included Charles Andler and Henri Lichtenberger. But the most influential of all was Henri Albert, born as Henri-Albert Haug, an Alsatian of Germanic ancestry.

Henri Albert was basically a journalist whose life mission was to translate and promote Nietzsche. From 1895 he was in charge of the Mercure de France project to publish Nietzsche's works in French, negotiating the translation rights with Nietzsche's sister and actually translating most of the texts himself. Albert also worked as a twoway intermediary, publishing notes on French literature in German periodicals at the same time as he commented on German literature in French periodicals. In a sense, he was the complete intercultural figure.

As with the Belgian translators of Wagner, Albert was occasionally criticized in the Parisian periodicals because of his marginal status with respect to the French target language and culture. When the Mercure publication project was announced at the end of 1894 through a call for translators willing to participate, it immediately drew a negative response from one Hughes Rebell (1895), who was outraged to hear that just anyone could be invited to translate Nietzsche's aristocratic thought. The translators should be of the same aristocratic order as Nietzsche (at that stage rumored to be from the Polish nobility), and Albert obviously was not. Indeed, Schockenhoff (1986) sees Rebell's rebuke as a direct response to Albert's peripheral status as an Alsatian. Wyzewa, now an established conservative critic, conveyed the same distance in ironically referring to Albert as "the self-appointed interpreter and faithful apostle of Nietzschéisme" (1896: 689).

The important point to note about Albert's intercultural origins is that they were not a sign of neutrality but instead contributed to his genuine and generalized rejection of German culture, coloring his entire perception of Nietzsche. The German occupation of Alsace threw a long shadow over Albert's sentimental and professional life. Yet this did not hinder his attachment to the German-language writer. Nietzsche had, after all, lived in other parts of the same intercultural space, in Basle, with sojourns in Nice and northern Italy. Such was the image that Albert consistently propagated through his commentaries and choice of texts for translation. Nietzsche was supposed to be spiritually French, as was his translator (see Pym 1998b for the rest of the story).

\section{Intercultural space in periodicals}

These strategies intricately concern not just who translates but also how one is expected to translate. Through them, we find the Parisian center reasserting its dominance over mediation through intercultural space. No matter how many translations came in from German, no matter how many actual exchanges there were with German periodicals, there was to be no cultural peace with the traditional enemy. 
Similar sentiments can be found on the German side. As a prime example, in 1889 M. G. Conrad, founder and director of Die Gesellschaft, launched into the final of three diatribes against the importation of French culture, throwing out denunciations of "Ausländerei," "französische Afterpoeten," "Französelei," and similar insults that should not be translated, all the while accusing the French of not importing enough of German culture: "We do not have any exchange relation with the French" (1889: 1689). If there was going to be basic understanding between these two sides in the 1890 s, the path was not going to be easy.

Two instances nevertheless indicate that the periodicals themselves were prepared to intervene in history, trying to turn their networks into determining factors. The first instance is a model of exchange between periodicals. In 1895 the Mercure de France and the Neue Deutsche Rundschau conducted coordinated surveys, both asking the following question: "All politics aside, are you in favor of closer intellectual and social relationships between France and Germany, and what would be the best means to attain such relationships?." The question suggests the required response. The responses from both sides were translated and published in the two periodicals, as a means of attaining the desired relationships. True, the positions expressed in those responses were not always quite so clear: they included extreme individualism, aristocratic elitism, the role of Zwischenstaate in a United States of Europe, the need to counter the future economic might of the United States, calls for a military buildup on the part of France, and indeed the belief that French and German cultures would never agree on anything. The exchange is not quite balanced, since several of the less patriotic German replies are only printed in the Mercure. The range is thus greater in the French publication, where the replies fill a respectable total of 67 pages. Within this range, the position of translators and professional intermediaries is rather ambiguous. One might expect them to be the most internationalist of intellectuals, but they in fact take great care to distance their subjectivity from their intercultural profession. Perhaps because they are afraid of being called traitors, they are among the most virulent believers in long-term cultural difference. The translator Henri Albert is there, ironically denouncing those who use their Alsatian origins as a "political trampoline."

The impact of this reciprocal survey was nevertheless short-lived. A second survey, specifically on the question whether Alsace-Lorraine should be French or German, was published by the Mercure de France in 1897. The replies now fill 172 pages. We find the question inviting positions clearly against Germany, and the invitation is largely accepted. The intercultural figures follow this trend, which might indeed indicate general tendency in both countries in the course of the 1890s. As relations between France and Germany deteriorated, the networks appear to have unraveled in precisely the space where one would hope to find a professional middle ground. The periodicals broke off many of their weaker intercultural links. Mediators went one way or the other, becoming patriots or traitors. The stage was set for the confrontations of the Dreyfus Affair in 1898, focused on a Jew from Alsace who was accused of spying for the Germans.

Yet there was a second attempt at an active interculture. Around the turn of the century we find several new petites revues exclusively dedicated to anti-nationalist stances. These include the Magazine International and the bilingual Revue francoallemande / Deutsch-französische Rundschau. The latter took clear objection to 
Albert's denial of Nietzsche's Germanness. Albert's reply was delivered from his now ensconced place at the Mercure de France: "I look at Germany, I look at Nietzsche, and the more I look, the more I understand that they were not made for each other" (Albert 1900: 848). Whereas one small intercultural network (the bilingual and multilingual periodicals) sought to underline Nietzsche's Germanness as part of a rapprochement between France and Germany, Nietzsche's main translator and promoter in France insisted on precisely the opposite, implicitly arguing against any cultural union.

The sub-network in intercultural space was once again very short-lived. Despite the many translations, French and German cultures entered the new century with little profound understanding of each other. World wars awaited.

\section{NOTE}

* The archival research reported in this paper was carried out at the Georg-August Universität Göttingen in 1992-94 with a grant from the Alexander von Humboldt Stiftung. The final version of the paper was written while the author was Visiting Professor at the University of Western Sydney. To all those institutions, our thanks.

\section{REFERENCES}

Albert, H. (1900): "Lettres allemandes," Mercure de France, 36, pp. 843-849.

Barnes, J. A. (1954): "Class and Committees in a Norwegian Island Parish," Human Relations, 7-1, pp. 39-58.

Berkowitz, S. D. (1982): An Introduction to Structural Analysis: The Network Approach to Social Research, Toronto, Butterworths.

Boissevain, J. (1974): Friends of Friends: Networks, Manipulators and Coalitions, Oxford, Blackwell.

Boissevain, J. and J. C. Mitchell (1973): Network Analysis: Studies in Human Interaction, The Hague, Mouton.

Bourdieu, P. (1980): "Une science qui dérange," interview with Pierre Thuillier, La Recherche 112 (June 1980), reprinted in Questions de sociologie, Paris, Minuit, pp. 19-36.

Conrad, M. G. (1889): "Wie stellen wir uns zu den Franzosen?," Die Gesellschaft Dez. 1889, pp. 1689-1690.

DécAudin, M. (1960): La crise des valeurs symbolistes: 20 ans de poésie française (1895-1914), Toulouse, Privat.

Derrida, J. (1967): De la grammatologie, Paris, Minuit.

Dujardin, E. (1886): Introductory note to "Lor du Rhein. Traduction française littérale de la première scène," Revue Wagnérienne, 1-8/9, pp. 257-258.

DuMÉRIL, E. (1934): Lieds et ballades germaniques traduits en vers français. Essai de bibliographie critique, reprint, Geneva, Slatkine, 1977.

KAPFERER, B. (1969): "Norms and the manipulation of relationships in a work context," in Mitchell, J. C. (ed.), Social Networks in Urban Situations, Manchester, Manchester University Press, pp. 181-244.

Latour, B. (1987): Science in Action. How to Follow Scientists and Engineers Through Society, Cambridge, Harvard University Press.

Latour, B. (1988): The Pasteurization of France, Cambridge, Harvard University Press.

Luhmann, N. (1995): Die Kunst der Gesellschaft, Frankfurt a.M., Suhrkamp.

Lyons, M. (1987): Le Triomphe du Livre: une histoire sociologique de la lecture dans la France du 19 e siècle, Paris, Promodis.

Milroy, L. (1987): Language and Social Networks, Second Edition (first edition 1980), Oxford and New York, Blackwell. 
Mitchell, J. C. (1973): "Networks, norms and institutions," in Boissevain, J. and J. C. Mitchell (eds.), Network Analysis: Studies in Human Interaction, The Hague, Mouton, pp. 15-36.

Nordau, M. (1892-1893): Entartung, Berlin, Carl Duncker.

Parsons, T. (1951): The Social System, Glencoe Il., Free Press.

Рyм, A. (1988): “Les notions de 'réseau' et de 'régime' en relations littéraires internationales," in Pyм, A., (ed.), L'Internationalité littéraire, Paris et Barcelone, Noesis, pp. 5-21.

Pyм, A. (1993): "Negotiation theory as an approach to translation history. An inductive lesson from fifteenth-century Castile," in Gambier, Y. and J. Tommola (eds.), Translation and Knowledge, Turku, University of Turku, Centre for Translation and Interpreting, pp. 27-39.

Pyм, A. (1998a): Method in Translation History, Manchester, St Jerome Publishing.

Pym, A. (1998b): "Lives of Henri Albert, Nietzschean Translator," in Beylard-Ozeroff, Králová, J. and B. Moser-Mercer (eds.), Translators' Strategies and Creativity, Amsterdam and Philadelphia, John Benjamins, pp. 117-125.

Rebell, H. (1895): "Sur une traduction collective des oeuvres de Nietzsche," Mercure de France, 13, pp. 98-102.

SCHLÖsser, A. (1937): Die englische Literatur in Deutschland von 1895 bis 1934, Jena, Biedermann.

Schockenhoff, A. (1986): Henri Albert und das Deutschlandbild des Mercure de France 18901905, Frankfurt/Main, Bern, New York, Peter Lang.

WiLly (1894): "Une nouvelle traduction de la Walkyrie," La Plume, 130 (15 sept.), pp. 382-383.

WiLly (1895): "Le gaffeur Kufferath," L’Ermitage, 10-1, pp. 42-44.

Wyzewa, T. de (1896): "La Jeunesse de Frédéric Nietzsche," Revue des Deux-Mondes, 133, pp. 688-699. 